\title{
Analyzing and identifying novel B cell epitopes within Toxoplasma gondii GRA4
}

\author{
Yanhua Wang ${ }^{1 *}$, Guangxiang Wang ${ }^{1}$, Jiangtao Ou ${ }^{2}$, Hong Yin ${ }^{1 *}$ and Delin Zhang ${ }^{1 *}$
}

\begin{abstract}
Background: The identification of specific epitopes targeted by the host antibody response is important for understanding the natural response to infection and for the development of epitope-based marker vaccines and diagnostic tools for toxoplasmosis. In this study, Toxoplasma gondii GRA4 epitopes were identified using software-based prediction and a synthetic peptide technique.

Methods: The complete GRA4 gene sequence was obtained from T. gondii of the Gansu Jingtai strain of tachyzoites. The potential B cell epitopes of GRA4 was predicted using the PROTEAN subroutine in the DNASTAR software package. The peptides with good hydrophilicity, high accessibility, high flexibility and strong antigenicity were chemically synthesized and assessed by ELISA using pig sera from different time points after infection.

Results: The potential B cell epitopes of GRA4 predicted by bioinformatics tools focused on six regions of GRA4, 52-77 aa, 93-112 aa, 127-157 aa, 178-201 aa, 223-252 aa and 314-333 aa. Eleven shorter peptides from the six regions were synthesized and assessed by ELISA using pig sera from different time points after infection. Three of the eleven peptides (amino acids 62-77, 233-252 and 314-333) tested were recognized by all sera.

Conclusions: We precisely located the T. gondii GRA4 epitopes using pig sera collected at different time points after infection. The identified epitopes may be useful for additional studies of epitope-based vaccines and diagnostic reagents.
\end{abstract}

Keywords: Toxoplasma gondii, GRA4, Epitope, Pig antibodies

\section{Background}

Toxoplasma gondii is an obligate intracellular parasite that infects a variety of mammals and birds, causing toxoplasmosis [1,2]. Toxoplasmosis is a zoonotic protozoan disease that is distributed worldwide [3-5]. T. gondii is an important foodborne parasite that is primarily transmitted from animals to humans through the consumption of infected meat [6-12]. In some countries, pork is the most common meat consumed, and several ethnic groups consume raw pork [13]. Pigs are considered the primary source of human infection with $T$. gondii $[14,15]$. Toxoplasmosis is a source of significant economic loss for swine farmers because of gross lesions in infected animals, which result in the carcass being condemned at the time of slaughter, the expense

\footnotetext{
*Correspondence: wangyh061001@163.com; yinhong@caas.net.cn; zhangd12005@163.com

${ }^{1}$ State Key Laboratory of Veterinary Etiological Biology, Lanzhou Veterinary Research Institute, Chinese Academy of Agricultural Sciences, Lanzhou 730046, China

Full list of author information is available at the end of the article
}

associated with treatment, and weight loss associated with clinical toxoplasmosis [16-19]. The development of effective diagnostic reagents or vaccines is an important goal because of the worldwide public health and economic repercussions of $T$. gondii infection [20,21].

Attempts to develop a peptide-based vaccine for $T$. gondii have been encouraging because they have demonstrated significant protection in murine models [22-25]. Using B cell epitopes for the serodiagnosis of toxoplasmosis presents several advantages, such as precise knowledge of the composition of the diagnostic antigen, the ability to use more than one identified B cell epitope, and easy standardization of the method [26]. The newly synthesized multiepitope antigen is one of the most promising antigens for the development of diagnostic kits for routine toxoplasmosis screening [27]. The identification of protein epitopes will be useful for diagnostic purposes and for the development of peptide vaccines [28-31]. The GRA proteins, which are highly expressed by the parasite, 
constitute the circulating antigens in the acute and chronic phases of infection and are of primary relevance to host immunity. Studies demonstrated the ability of several GRA antigens to confer protective immunity in mice infected with $T$. gondii [32,33], in particular GRA4 [17,34-38]. Reports demonstrated that GRA4 might be used to design novel and alternative diagnostic methods for toxoplasmosis $[39,40]$. These results indicated that GRA4 is a promising immunogenic candidate for the development of effective diagnostic reagents or subunit vaccines that induce an immunodominant response. For GRA4 epitopes, amino acids 229-242 and 231-245 induce humoral and cellular immune responses and these epitopes are defined as B and T-cell epitopes [41,42]. The GRA4 231-245 peptide is immunogenic and is considered a suitable alternative for epitope-based vaccine design. Only a few GRA4 epitopes have been defined.

With the development of bioinformatics, additional methods have been developed or adapted from other computational tools for the prediction of B cell epitopes. We used five available methods based on the properties of amino acids, Garnier-Robson [43] and Chou-Fasman beta-turn prediction [44], Kyte-Doolittle hydrophilicity prediction [45], Karplus-Schulz flexibility prediction [46], Emini surface accessibility prediction [47], and Jameson-Wolf antigenicity prediction [48], to study and analyze the potential epitopes of SAG1 and GRA1 $[29,30]$. Using experimental verification, we found that these five methods reliably predicted the results. All linear peptides from GRA4, which are recognized by the humoral immune response in pigs, have not been previously examined systematically. The B cell epitopes of GRA4 were analyzed using software-based prediction and a synthetic peptide technique.

\section{Methods}

\section{Serum samples}

A total of $51 \mathrm{~T}$. gondii-positive sera samples previously collected from pigs experimentally infected with the Gansu Jingtai strain (isolated from a pig with acute toxoplasmosis) in our laboratory (The experimental protocol was approved by the Ethical Committee of the Lanzhou Veterinary Research Institute, Chinese Academy of Agricultural Sciences) were evaluated in this study. Twelve pig serum samples were collected at the time of presentation of clinical symptoms (G1), 18 follow-up samples were collected on days 14 to 35 after the onset of symptoms (G2) and 21 samples were collected on days 60 to 120 after the onset of symptoms (G3). The presence of Toxoplasma IgM and IgG antibodies was determined by $T$. gondii lysate antigenELISA. The G1 and G2 samples were positive for IgM and IgG against $T$. gondii. The G3 samples were positive for IgG against $T$. gondii. Ten serum samples negative for T. gondii IgM and IgG were used as controls.
Amplification, cloning and sequencing of the GRA4 gene

To obtain the complete GRA4 gene sequence, a recombinant plasmid encoding the GRA4 gene was constructed as described below. T. gondii DNA was obtained from Gansu Jingtai strain tachyzoites using the Universal Genomic DNA Extraction kit (TaKaRa Biotechnology Co., Ltd, Dalian, China), and the GRA4 sequence was amplified using the primers 5'-GATACGTAATGCAGGGCACTTGGTTTT-3' and 5' - CGGAATTCTCACTCTTTGCGCATTCTT -3'. The PCR amplification was performed using the TaKaRa TaqTM kit according to the manufacturer's instructions. The sample was subjected to an initial denaturation $\left(94^{\circ} \mathrm{C}\right.$ for $5 \mathrm{~min}), 35$ cycles of denaturation $\left(94^{\circ} \mathrm{C}\right.$ for $\left.1 \mathrm{~min}\right)$, annealing $\left(60^{\circ} \mathrm{C}\right.$ for $\left.30 \mathrm{~s}\right)$ and elongation $\left(72^{\circ} \mathrm{C}\right.$ for $\left.1 \mathrm{~min}\right)$, and a final extension at $72^{\circ} \mathrm{C}$ for $10 \mathrm{~min}$. The PCR-generated fragment was purified and cloned into the pMD-18 T vector (TaKaRa Biotechnology Co., Ltd, Dalian, China). The recombinant plasmid was used to transform Escherichia coli JM 109 competent cells, and the recombinant cells were selected on LB plates with ampicillin (100 mg/L), X-Gal (5bromo-4-chloro-3-indolyl- $\beta$-D-galactopyranoside; $70 \mathrm{mg} / \mathrm{L}$ ) and IPTG (isopropyl beta-D-thiogalactopyranoside; $80 \mu \mathrm{M}$ ) at $37^{\circ} \mathrm{C}$ for $24 \mathrm{~h}$ (ampicillin, X-Gal and IPTG were from TaKaRa Biotechnology Co., Ltd, Dalian, China). Positive colonies were inoculated into LB liquid medium containing ampicillin $(100 \mathrm{mg} / \mathrm{L})$ and incubated at $37^{\circ} \mathrm{C}$ for $16 \mathrm{~h}$. The recombinant plasmid was extracted using a Plasmid Purification kit (TaKaRa Biotechnology Co., Ltd, Dalian, China). The positive colonies identified by PCR were sequenced by TaKaRa Biotechnology Co., Ltd (Dalian, China).

\section{Prediction of the epitopes}

To analyze the GRA4 B cell epitopes, the deduced amino acid sequence of GRA4 was analyzed using the PROTEAN subroutine in the DNASTAR software package. This subroutine uses the Garnier-Robson [43] and Chou-Fasman [44] algorithms for predicting the alpha, beta, and turn regions, the Garnier-Robson algorithm for predicting the coil regions, the Kyte-Doolittle [45] algorithm for predicting hydrophilicity, the Karplus-Schultz [46] algorithm for predicting flexibility, the Emini [47] algorithm for predicting surface probability and the Jameson-Wolf [48] algorithm for predicting antigenicity. Based on this analysis, the peptides with good hydrophilicity, high accessibility, high flexibility and strong antigenicity were selected as the antigen epitopes. These peptides were chemically synthesized by GL Biochem Ltd (Shanghai, China). The peptide sequences are shown in Table 1.

\section{ELISA analysis}

Enzyme-linked immunoassays specific for each peptide were performed as described by Cardona et al. [49] with minor modifications. The microplates were coated with $100 \mu \mathrm{l}(10 \mu \mathrm{g} / \mathrm{ml})$ of each peptide diluted in carbonate 
Table 1 Sequences of synthesized peptides

\begin{tabular}{lll}
\hline Peptides & Start and end position & Sequence \\
\hline P1 & $52-71$ aa & HSMYGNKTPYPYADGQQGSP \\
P2 & $62-77$ aa & PYADGQQGSPPPQGQL \\
P3 & $93-112$ aa & QGVPQAPQAAGGPGSPMNGG \\
P4 & $127-146$ aa & GTPGHPVQAIPQQPLRTQAT \\
P5 & $136-157$ aa & IPQQPLRTQATATYYHPAAAPP \\
P6 & $172-191$ aa & PGAEVTPGYSGLQLRQQSQY \\
P7 & $182-201$ aa & DYSYPGTTSTPTPPRPASYG \\
P8 & $192-211$ aa & GLQLRQQSQYDYSYPGTST \\
P9 & $223-242$ aa & AFSDSVSVSTEDSGLTVRD \\
P10 & $233-252$ aa & EDSGLTVRDSSSSESTVTP \\
P11 & $314-333$ aa & TELDDGYRPPPFNPRPSPYA \\
\hline
\end{tabular}

buffer, pH $9.6\left(\mathrm{Na}_{2} \mathrm{CO}_{3}: 0.159 \mathrm{~g} / 100 \mathrm{~mL} ; \mathrm{NaHCO}_{3}\right.$ : $0.293 \mathrm{~g} / 100 \mathrm{~mL}$ ). The plates were incubated for $1 \mathrm{~h}$ at $37^{\circ} \mathrm{C}$, then for $48 \mathrm{~h}$ at $4^{\circ} \mathrm{C}$ and $1 \mathrm{~h}$ at $37^{\circ} \mathrm{C}$. Non-specific ligand sites were blocked with $100 \mu \mathrm{l} 2 \%$ casein phosphate buffer for $1 \mathrm{~h}$ at $37^{\circ} \mathrm{C}$. The plates were washed and incubated with $100 \mu \mathrm{l}$ serum diluted to $1: 100$ in $5 \%$ casein phosphate buffer for $1 \mathrm{~h}$ at $40^{\circ} \mathrm{C}$. After washing, $100 \mu \mathrm{l}$ rabbit anti-pig peroxidase-conjugated IgG (Sigma) diluted to $1: 4000$ in $6 \%$ casein phosphate buffer was added for $20 \mathrm{~min}$ at $37^{\circ} \mathrm{C}$. After the washes, the horseradish peroxidase activity was detected using TMB for $30 \mathrm{~min}$ at $37^{\circ} \mathrm{C}$ and stopped with a $5 \% \mathrm{H}_{2} \mathrm{SO}_{4}$ solution. The absorbance of duplicates for each serum sample was measured at $450 \mathrm{~nm}$. A positive cut-off point was determined by estimating the mean average absorbance of ten negative controls plus two standard deviations.

To determine the specificity of the anti-peptide antibody, an ELISA using irrelevant peptides from the BL21 of the orf virus previously synthesized by our laboratory (sequence: VDVQSKDKDADELRE) was also performed as described above. As controls, ELISAs using soluble T. gondii antigen (STAg) and recombinant GRA4 from the RH strain of $T$. gondii previously expressed by our laboratory were also performed as described above, with minor modifications. Briefly, non-specific ligand sites were blocked with $100 \mu \mathrm{l}$ 5\% BSA phosphate buffer. Pig sera were diluted 1:100 in PBS and used as the primary antibody. The rabbit anti-pig peroxidase-conjugated IgG diluted 1:8000 in PBS was used as the secondary antibody.

\section{Results and discussion}

Bioinformatics is important for predicting protein structure, function and biological characteristics. With the aid of software and databases for the prediction of epitopes, we can reduce the number of proteins of interest and significantly decrease the number of laboratory experiments. Bioinformatics has been widely used in the analysis of protein epitopes [50-54]. In the present study, the secondary structure of GRA4 was predicted by the Garnier-Robson and Chou-Fasman algorithms based on the sequence of the GRA4 gene. A flexibility plot, hydrophilicity plot, surface probability plot and antigenic index for GRA4 were obtained using the Karplus-Schulz, Kyte-Doolittle, Emini and Jameson-Wolf algorithms, respectively (Figure 1). The variability, fragment mobility, and hydrophilicity are important features of antigenic epitopes. The existence of flexible regions, such as coil and turn regions, provides powerful evidence for epitope identification $[53,54]$. Based on the results obtained with these methods, potential B cell epitopes on GRA4 were predicted, including 52-71 aa, 62-77 aa, 93-112 aa, 127-146 aa, 136-157 aa, 172-191 aa, $182-201$ aa, $192-211$ aa, $223-242$ aa, 233-252 aa and 314-333 aa.

In the past, several experimental techniques were developed for mapping antibody interacting residues on an antigen, including the identification of interacting

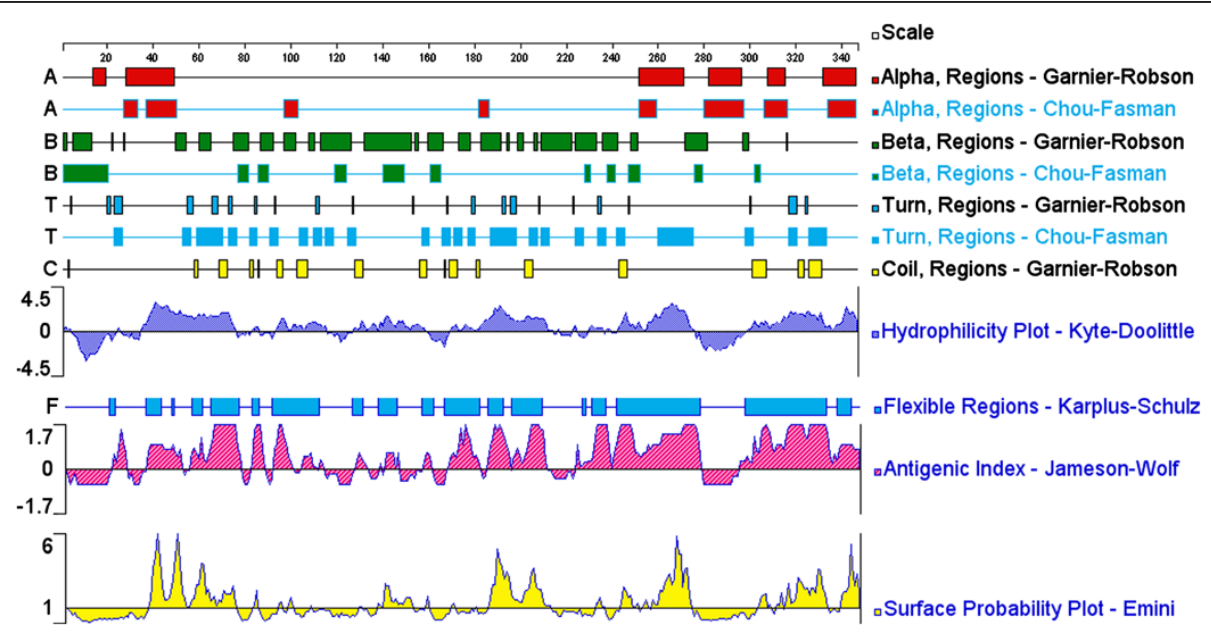

Figure 1 The secondary structures, flexibility, hydrophilicity, surface probability and antigenicity index for T. gondii GRA4. 

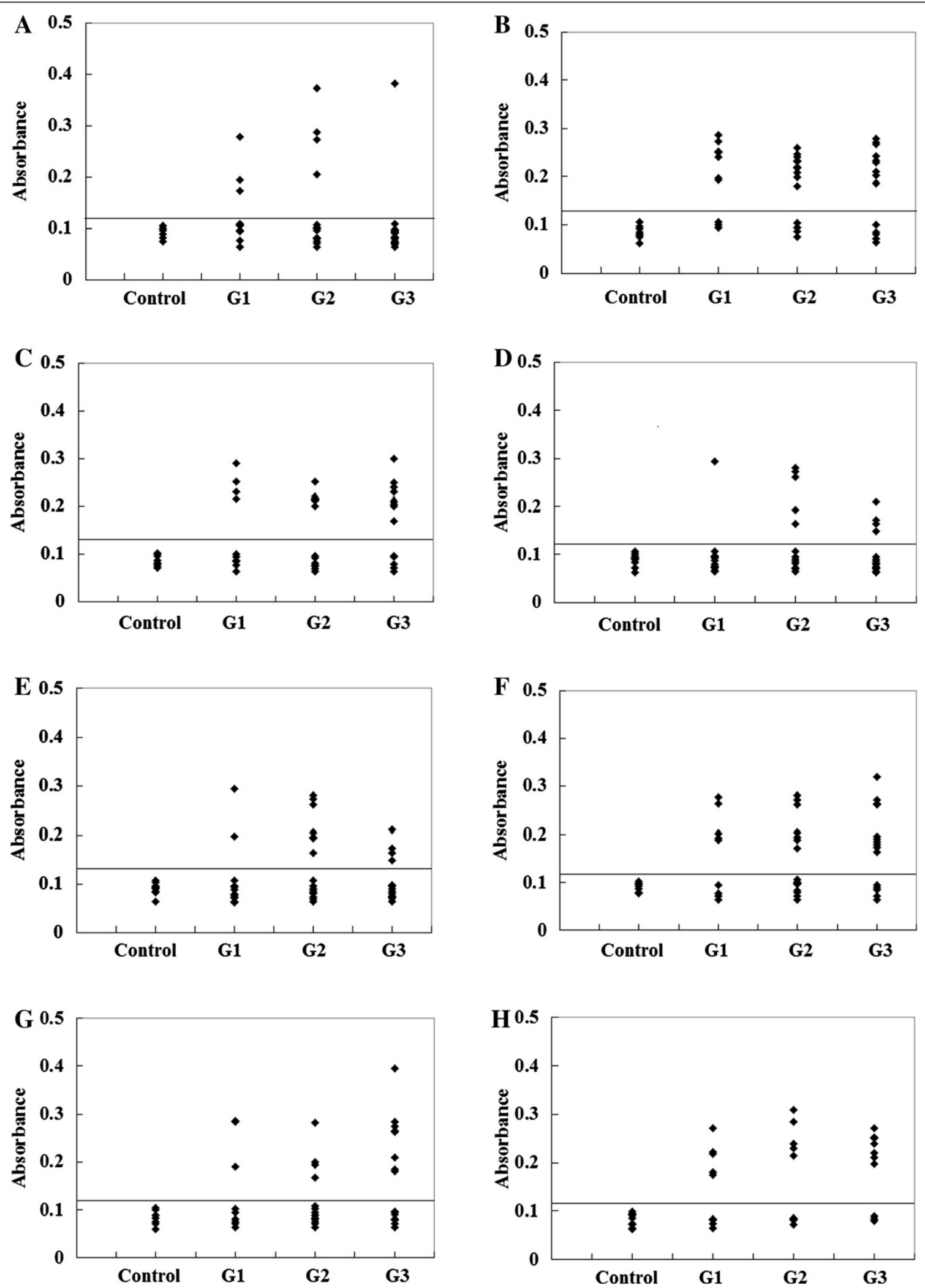

Figure 2 ELISA of IgG antibodies against different peptides in the four groups of pig sera. (A), (B), (C), (D), (E), (F), (G) and (H) showing the absorbances targeting P1, P3, P4, P5, P6, P7, P8, and P9, respectively. The cut-off point for the assay is indicated by the horizontal line. 
residues from the structure of antibody-antigen complexes $[55,56]$. One popular approach is the synthetic peptide technique, which primarily identifies sequential epitopes [56]. Using this technique, we verified the validity of the predicted epitopes in the present study. All eleven of the predicted epitope peptides were evaluated by ELISA

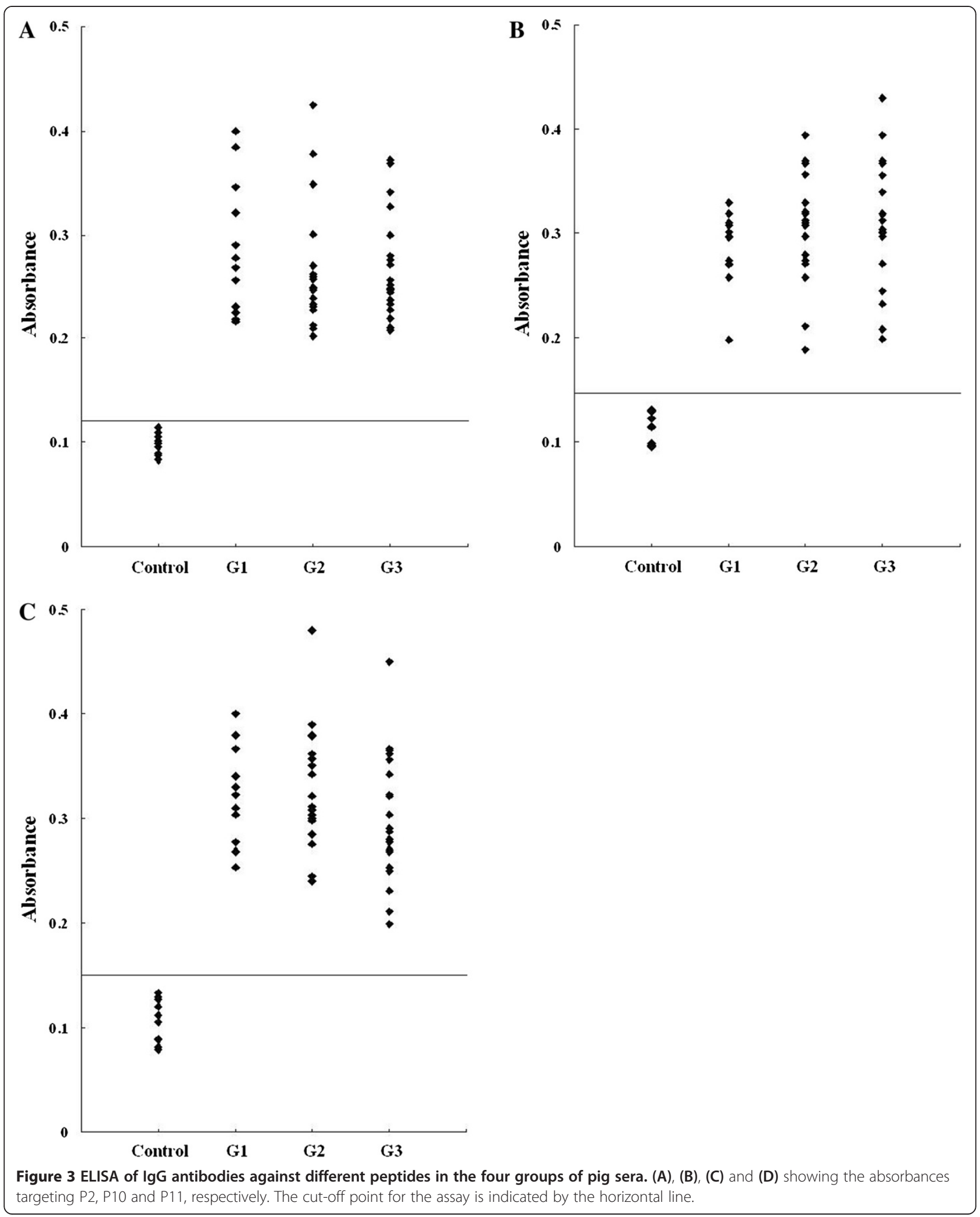


using pig sera from various time points after infection. P2, P10 and P11 were recognized by all sera. The other eight peptides were recognized by select sera from various time points after infection (Figure 2; number of positive samples/ tested for each peptide as follows: P1:7/51, P3:36/51, P4:23/
51, P5:12/51, P6:17/51, P7:27/51, P8:18/51 and P9:21/51). The results of the ELISA for three peptides, P2, P10 and P11, are shown in Figure 3. For each of the three peptides, no significant differences were observed between the mean absorbances of the three groups (G1, G2 and G3)
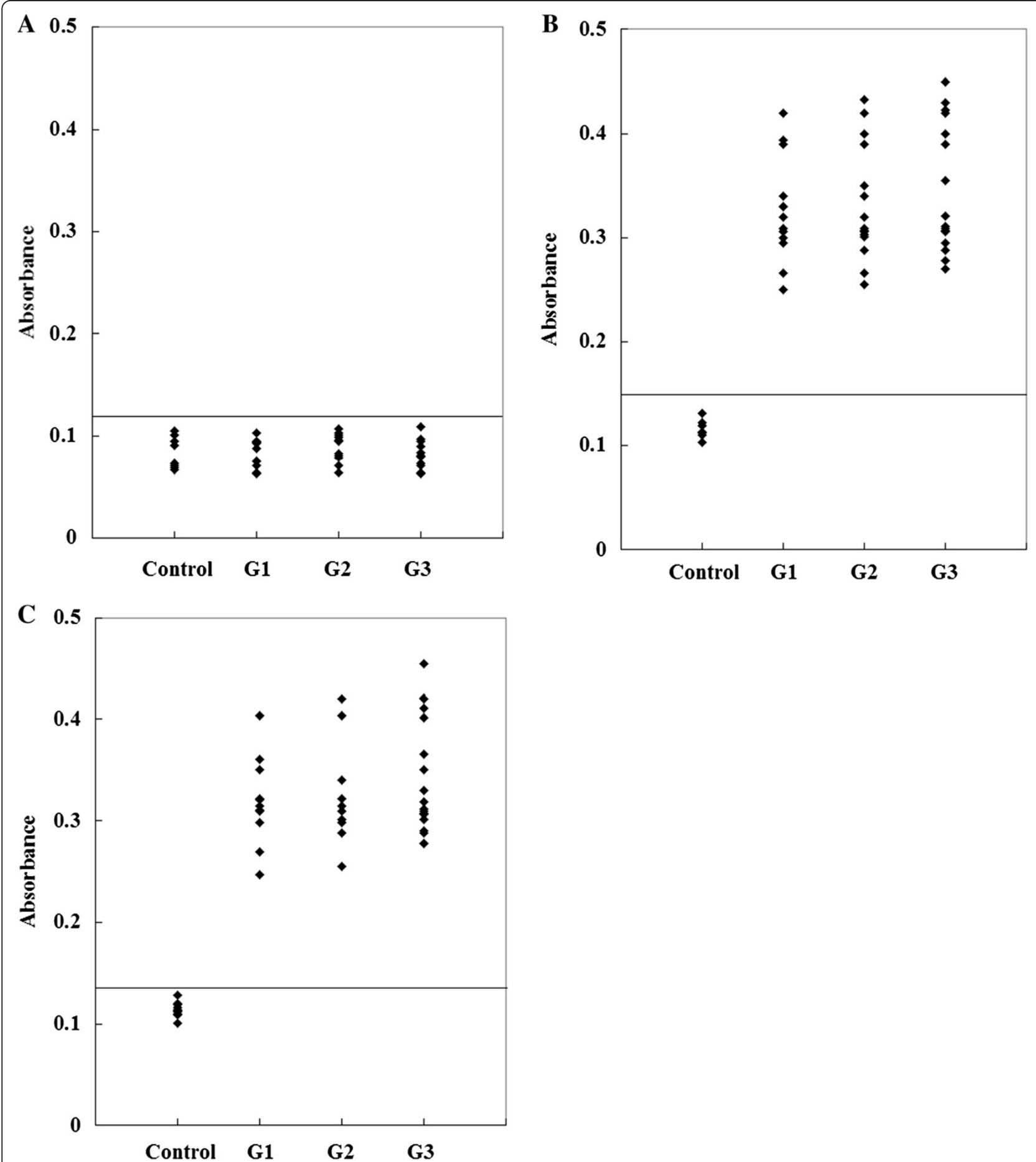

Figure 4 ELISA of IgG antibodies against an irrelevant peptide (A), STAg (B) and recombinant GRA4 (C) in the four groups of pig sera. The cut-off point for the assay is indicated by the horizontal line. 
as determined by ANOVA. Furthermore, no significant differences were observed between the mean absorbances of the three peptides, P2, P10 and P11. In our study, we found that the three peptides derived from GRA4 were recognized by pig sera from different time points after infection. The reactivity of these epitopes does not seem to be dependent upon the time of infection, suggesting that the host response is constantly activated by these protein fragments.

To determine the specificity of the anti-peptide antibody, an ELISA using an irrelevant peptide was also performed. This peptide did not react with the sera (Figure 4A). To compare the serological reactivity of the peptides with STAg and recombinant GRA4, ELISAs using STAg and recombinant GRA4 were also performed. A total of 51 sera samples reacted with STAg (Figure 4B) and recombinant GRA4 (Figure 4C).

Many tools for identifying and predicting B cell epitopes have been developed previously $[50,51,55,56]$. Conformational epitope selection relies on the determination of the tertiary structure of an antigen to identify residues that interact with antibodies. The experimental techniques required to determine the tertiary structure of the antigen, such as crystallography, are expensive and time consuming, and the mapping of conformational epitopes has been severely hampered. The majority of methods and databases have focused on the identification of linear epitopes [57,58]. In the present study, linear epitopes were analyzed using software-based predictions, and three of the eleven predicted epitope peptides were confirmed by synthetic peptide techniques. The use of a bioinformatics method in combination with a molecular biology method is a useful method to screen for linear epitopes.

\section{Conclusion}

Using peptide synthesis techniques and software-based prediction of epitopes, we found that many regions of GRA4, particularly the regions represented by peptides $\mathrm{P} 2, \mathrm{P} 10$ and P11, are involved in the pig antibody response, and good reactivity with the $T$. gondii-infected pig sera was observed. The identification of B cell epitopes is important for understanding antigenic structure and parasite-antibody interactions at the molecular level and may assist in the design of vaccines and diagnostic reagents. The identification of B cell epitopes is an exciting area of development. There are more linear and conformational B cell epitopes than previously predicted; therefore, the number of identified epitopes should also increase with additional studies.

\section{Competing interests}

The authors declare that they have no competing interests.

\section{Authors' contributions}

YHW, HY and DLZ designed the experiment. YHW, GXW and JTO performed the laboratory studies. YHW drafted the manuscript. All authors read and approved the final manuscript.

\section{Acknowledgments}

This study was supported by grants from the Natural Science Foundation of Gansu Province, China (145RJZA234) and NBCITS, MOA (CARS-38).

\section{Author details}

${ }^{1}$ State Key Laboratory of Veterinary Etiological Biology, Lanzhou Veterinary Research Institute, Chinese Academy of Agricultural Sciences, Lanzhou 730046, China. ${ }^{2}$ School of Chemical and Biological Engineering, Yancheng Institute of Technology, 9 Yingbin Road, Yancheng 224051, China.

Received: 28 April 2014 Accepted: 3 October 2014

Published online: 10 October 2014

\section{References}

1. Glor SB, Edelhofer R, Grimm F, Deplazes P, Basso W: Evaluation of a commercial ELISA kit for detection of antibodies against Toxoplasma gondii in serum, plasma and meat juice from experimentally and naturally infected sheep. Parasit Vectors 2013, 6:85

2. Sun X, Lu H, Jia B, Chang Z, Peng S, Yin J, Chen Q, Jiang N: A comparative study of Toxoplasma gondii seroprevalence in three healthy Chinese populations detected using native and recombinant antigens. Parasit Vectors 2013, 6:241.

3. Chadwick EA, Cable J, Chinchen A, Francis J, Guy E, Kean EF, Paul SC, Perkins SE, Sherrard-Smith E, Wilkinson C, Forman DW: Seroprevalence of Toxoplasma gondii in the Eurasian otter (Lutra lutra) in England and Wales. Parasit Vectors 2013, 6:75.

4. Lilly EL, Wortham CD: High prevalence of Toxoplasma gondii oocyst shedding in stray and pet cats (Felis catus) in Virginia, United States. Parasit Vectors 2013, 6:266.

5. Mwambe B, Mshana SE, Kidenya BR, Massinde AN, Mazigo HD, Michael D, Majinge C, Groß U: Sero-prevalence and factors associated with Toxoplasma gondii infection among pregnant women attending antenatal care in Mwanza, Tanzania. Parasit Vectors 2013, 6:222.

6. Boughattas S, Bergaoui R, Essid R, Aoun K, Bouratbine A: Seroprevalence of Toxoplasma gondii infection among horses in Tunisia. Parasit Vectors 2011, 4:218.

7. Dubey JP: Toxoplasmosis in pig-the last 20 years. Vet Parasitol 2009 164:89-103.

8. Dubey JP, Baker DG, Davis SW, Urban JF, Shen SK: Persistence of immunity to toxoplasmosis in pigs vaccinated with a non-persistent strain of Toxoplasma gondii. Am J Vet Res 1994, 55:982-987.

9. Fajardo HV, D'ávila S, Bastos RR, Cyrino CD, de Lima Detoni M, Garcia JL, das Neves LB, Nicolau JL, Amendoeira MR: Seroprevalence and risk factors of toxoplasmosis in cattle from extensive and semi-intensive rearing systems at Zona da Mata, Minas Gerais state, Southern Brazil. Parasit Vectors 2013, 6:191.

10. Lind P, Haugegaard J, Wingstrand A, Henriksen SA: The time course of the specific antibody response by various ELISAs in pigs experimentally infected with Toxoplasma gondii. Vet Parasitol 1997, 71:1-15.

11. Pardini L, Maksimov P, Herrmann DC, Bacigalupe D, Rambeaud M, Machuca M, Moré G, Basso W, Schares G, Venturini MC: Evaluation of an in-house TgSAG1 (P30) IgG ELISA for diagnosis of naturally acquired Toxoplasma gondii infection in pigs. Vet Parasitol 2012, 189:204-210.

12. Yang N, Mu MY, Li HK, Long M, He JB: Seroprevalence of Toxoplasma gondii infection in slaughtered chickens, ducks, and geese in Shenyang, northeastern China. Parasit Vectors 2012, 5:237.

13. Zou FC, Sun XT, Xie YJ, Li B, Zhao GH, Duan G, Zhu XQ: Seroprevalence of Toxoplasma gondii in pigs in Southwestern China. Parasitol Int 2009, 58:306-307.

14. Ortega-Pacheco A, Acosta-Viana KY, Guzman-Marin E, Uitzil-Álvarez B, Rodríguez-Buenfil JC, Jimenez-Coello M: Infection dynamic of Toxoplasma gondii in two fattening pig farms exposed to high and low cat density in an endemic region. Vet Parasitol 2011, 175:367-371.

15. Wang $M$, Wang $Y H$, Ye Q, Meng $P$, Yin H, Zhang DL: Serological survey of Toxoplasma gondii in Tibetan mastiffs (Canislupus familiaris) and yaks (Bos grunniens) in Qinghai, China. Parasit Vectors 2012, 5:35. 
16. Holec-Gąsior L, Kur J: Toxoplasma gondii: Recombinant GRA5 antigen for detection of immunoglobulin $\mathrm{G}$ antibodies using enzyme-linked immunosorbent assay. Exp Parasitol 2010, 124:272-278.

17. Sánchez VR, Pitkowski MN, Fernández Cuppari AV, Rodríguez FM, Fenoy IM, Frank FM, Goldman M, Corral RS, Martin V: Combination of CpG-oligodeoxynucleotides with recombinant ROP2 or GRA4 proteins induces protective immunity against Toxoplasma gondii infection. Exp Parasitol 2011, 128:448-453.

18. Sun XS, Zou J, Elashram Saeed AA, Yan WC, Liu XY, Suo X, Wang H, Chen QJ: DNA vaccination with a gene encoding Toxoplasma gondii GRA6 induces partial protection against toxoplasmosis in BALB/c mice. Parasit Vectors 2011, 4:213.

19. Wang YH, Zhang DL, Wang GX, Yin H, Wang M: Immunization with excreted-secreted antigens reduces tissue cyst formation in pigs. Parasitol Res 2013, 112:3835-3842.

20. Cong H, Zhang M, Xin Q, Wang Z, Li Y, Zhao Q, Zhou H, He S: Compound DNA vaccine encoding SAG1/ SAG3 with $A 2 / B$ subunit of cholera toxin as a genetic adjuvant protects BALB/c mice against Toxoplasma gondii. Parasit Vectors 2013, 6:63

21. Meng M, He S, Zhao G, Bai Y, Zhou H, Cong H, Lu G, Zhao Q, Zhu XQ: Evaluation of protective immune responses induced by DNA vaccines encoding Toxoplasma gondii surface antigen 1 (SAG1) and 14-3-3 protein in BALB/c mice. Parasit Vectors 2012, 5:273.

22. Cong H, Gu QM, Yin HE, Wang JW, Zhao QL, Zhou HY, Li Y, Zhang JQ: Multi-epitope DNA vaccine linked to the A2/B subunit of cholera toxin protect mice against Toxoplasma gondii. Vaccine 2008, 26:3913-3921.

23. Darcy F, Maes P, Gras-Masse H: Protection of mice and nude rats against toxoplasmosis by a multiple antigenic peptide construction derived from Toxoplasma gondii P30 antigen. J Immunol 1992, 149:3636-3641.

24. Godard I, Estaquier J, Zenner L, Bossus M, Auriault C, Darcy F, Gras-Masse H, Capron A: Antigenicity and immunogenicity of P30-derived peptides in experimental models of toxoplasmosis. Mol Immunol 1994, 31:1353-1363.

25. Wang $Y H$, Wang $M$, Wang GX, Pang AN, Fu BQ, Yin H, Zhang DL: Increased survival time in mice vaccinated with a branched lysine multiple antigenic peptide containing B- and T-cell epitopes from T. gondii antigens. Vaccine 2011, 29:8619-8623.

26. Liu X, Han Z, Shao Y, Yu D, Li H, Wang Y, Kong X, Liu S: Identification of a novel linear B-cell epitope in the UL26 and UL26.5 proteins of duck enteritis virus. Virol J 2010, 7:223

27. Dai JF, Jiang M, Wang YY, Qu LL, Gong RJ, Si J: Evaluation of a recombinant multiepitope peptide for serodiagnosis of Toxoplasma gondii infection. Clin Vaccine Immuno/ 2012, 19:338-342

28. Kolaskar AS, Tongaonkar PC: A semi-empirical method for prediction of antigenic determinants on protein antigen. FEBS Lett 1990, 276:172-174.

29. Wang $Y H$, Wang GX, Zhang DL, Yin H, Wang M: Screening and identification of novel B cell epitopes of Toxoplasma gondii SAG1. Parasit Vectors 2013, 6:125.

30. Wang $Y H$, Wang GX, Zhang DL, Yin H, Wang M: Identification of novel B cell epitopes within Toxoplasma gondii GRA1. Exp Parasitol 2013, 135:606-610.

31. Wang $Y$, Yin $\mathrm{H}$ : Research progress on surface antigen 1 (SAG1) of Toxoplasma gondii. Parasit Vectors 2014, 7:180

32. Desolme B, Mevelec MN, Buzoni-Gatel D, Bout D: Induction of protective immunity against toxoplasmosis in mice by DNA immunization with a plasmid encoding Toxoplasma gondii GRA4 gene. Vaccine 2000, 18:2512-2521.

33. Vercammen M, Scorza T, Huygen K, De Braekeleer J, Diet R, Jacobs D, Saman E, Verschueren H: DNA vaccination with genes encoding Toxoplasma gondii antigens GRA1, GRA7, and ROP2 induces partially protective immunity against lethal challenge in mice. Infect Immun 2000, 68:38-45.

34. Martin V, Supanitsky A, Echeverria PC, Litwin S, Tanos T, De Roodt AR, Guarnera EA, Sergio O, Angel SO: Recombinant GRA4 or ROP2 protein combined with alum or the gra4 gene provides partial protection in chronicmurinemodels of toxoplasmosis. Clin Diag Lab Immuno/ 2004, 11:704-710.

35. Mevelec MN, Bout D, Desolme B, Marchand H, Magné R, Bruneel O, Buzoni-Gatel D: Evaluation of protective effect of DNA vaccination with genes encoding antigens GRA4 and SAG1 associated with GM-CSF plasmid, against acute, chronical and congenital toxoplasmosis in mice. Vaccine 2005, 23:4489-4499.

36. Mevelec MN, Mercereau-Puijalon O, Buzoni-Gatel D, Bourguin I, Chardès T, Dubremetz JF, Bout D: Mapping of B epitopes in GRA4, a dense granule antigen of Toxoplasma gondii and protection studies using recombinant proteins administered by the oral route. Parasite Immunol 1998, 20:183-195.
37. Zhang G, Huong VT, Battur B, Zhou J, Zhang H, Liao M, Kawase O, Lee EG, Dautu G, Igarashi M, Nishikawa Y, Xuan X: A heterologous prime-boost vaccination regime using DNA and a vaccinia virus, both expressing GRA4, induced protective immunity against Toxoplasma gondii infection in mice. Parasitology 2007, 134:1339-1346.

38. Ram H, Rao JR, Tewari AK, Banerjee PS, Sharma AK: Molecular cloning, sequencing, and biological characterization of GRA4 gene of Toxoplasma gondii. Parasitol Res 2013, 112:2487-2494.

39. Altcheh J, Diaz NS, Pepe CM, Martin V, Nigro M, Freilij H, Angel SO: Kinetic analysis of the humoral immune response against 3 Toxoplasma gondii-recombinant proteins in infants with suspected congenital toxoplasmosis. Diagn Microbiol Infect Dis 2006, 56:161-165.

40. Nigro M, Gutierrez A, Hoffer AM, Clemente M, Kaufer F, Carral L, Martin V, Guarnera EA, Angel SO: Evaluation of Toxoplasma gondii recombinant proteins for the diagnosis of recently acquired toxoplasmosis by an immunoglobulin G analysis. Diagn Microbiol Infect Dis 2003, 47:609-613.

41. Chardes T, Bourguin I, Mevelec MN, Dubremetz JF, Bout D: Antibody responses to Toxoplasma gondii in sera, intestinal secretions, and milk from orally infected mice and characterization of target antigens. Infect Immun 1990, 58:1240-1246.

42. Meisel R, Stachelhaus S, Mevelec MN, Reichmann G, Dubremetz JF, Fischer HG: Identification of two alleles in the GRA4 locus of Toxoplasma gondii determining a differential epitope which allows discrimination of type I versus type II and III strains. Mol Biochem Parasitol 1996, 81:259-263.

43. Garnier J, Robson B: The GOR method for predicting secondary structures in proteins. In Prediction of protein structure and the principles of protein conformation. Edited by Fasman GD. New York: Plenum press; 1989:417-465.

44. Chou PY, Fasman GD: Prediction of the secondary structure of proteins from their amino acid sequence. Adv Enzymol 1987, 47:45-148.

45. Kyte J, Doolittle RF: A simple method for displaying the hydropathic character of a protein. J Mol Biol 1982, 157:105-132.

46. Karplus PA, Schulz GE: Prediction of chain flexibility in proteins: a tool for the selection of peptide antigens. Naturwissenschaften 1985, 72:212-213.

47. Emini EA, Hughes JV, Perlow DS, Boger J: Induction of hepatitis A virus-neutralizing antibody by a virus-specific synthetic peptide. J Virol 1985, 55:836-839.

48. Jameson BA, Wolf H: The antigenic index: a novel algorithm for predicting antigenic determinants. Comput Appl Biosci 1988, 181:212-213.

49. Cardona N, de-la-Torre A, Siachoque H, Patarroyo MA, Gomez-Marin JE: Toxoplasma gondii: P30 peptides recognition pattern in human toxoplasmosis. Exp Parasitol 2009, 123:199-202.

50. Ansari HR, Raghava GPS: Identification of conformational B-cell epitopes in an antigen from its primary sequence. Immunome Res 2010, 6:6.

51. Sollner J, Grohmann R, Rapberger R, Perco P, Lukas A, Mayer B: Analysis and prediction of protective continuous B-cell epitopes on pathogen proteins. Immunome Res 2008, 4:1.

52. Sharma P, Gaur SN, Arora N: In silico identification of IgE-binding epitopes of osmotin protein. PLoS One 2013, 8:e54755.

53. Yang B, He SY, Zhao GH, Chen L, Shi N, Zhou HY, Cong H, Zhao QL, Zhu $\mathrm{XQ}$ : Toxoplasma gondii: bioinformatics analysis, cloning and expression of a novel protein TgIMP1. Exp Parasitol 2012, 132:458-464.

54. Zhang ZW, Zhang YG, Wang $Y L$, Pan L, Fang $Y Z$, Jiang ST, Lu JL, Zhou P: Screening and identification of $B$ cell epitopes of structural proteins of foot-and-mouth disease virus serotype Asia I. Vet Microbiol 2010, 140:25-33.

55. Van Regenmortel MH: Structural and functional approaches to the study of protein antigenicity. Immunol Today 1989, 10:266-272.

56. Frank R: The SPOT-synthesis technique. Synthetic peptide arrays on membrane supports-principles and applications. J Immunol Methods 2002, 267:13-26.

57. Saha S, Raghava GP: Searching and mapping of B-cell epitopes in Bcipep database. Methods Mol Biol 2007, 409:113-124.

58. Vita R, Zarebski L, Greenbaum JA, Emami H, Hoof I, Salimi N, Damle R, Sette A, Peters B: The immune epitope database 2.0. Nucleic Acids Res 2010, 38:D854-D862.

doi:10.1186/s13071-014-0474-x

Cite this article as: Wang et al:: Analyzing and identifying novel B cell epitopes within Toxoplasma gondii GRA4. Parasites \& Vectors 2014 7:474 